\title{
Species of Anisepyris Kieffer, 1905 (Hymenoptera, Bethylidae) collected in Cachoeira da Fumaça and Forno Grande State Parks, Espírito Santo, Brazil
}

Hélio Sá Santos ${ }^{1}$

\begin{abstract}
Six species of Anisepyris Kieffer, 1905 were collected in Cachoeira da Fumaça (Alegre) and Forno Grande (Castelo) State Parks. Two of them are already known: Anisepyris lobatus Santos \& Azevedo, 2000 and Anisepyris rectus Santos \& Azevedo, 2000. Other four are described as new: Anisepyris attenuatus sp. nov., Anisepyris divisus sp. nov., Anisepyris inconspicuus sp. nov., and A. rotundus sp. nov.; each new species is illustrated. Two uncommon characters for Anisepyris, such as an inconspicuous anterior carina of the pronotum, and a lower mesopleural fovea partially open on the lower margin were observed being both the characters found in $A$. inconspicuus sp. nov. and only the first character in $A$. attenuatus sp. nov.
\end{abstract}

Keywords. Anisepyris; Bethylidae; Brazil; Hymenoptera; systematics.

\section{INTRODUCTION}

Anisepyris Kieffer, 1905 is a large genus of Bethylidae with 82 known species restricted to the American continent. WestwoOd (1874), KIEFFER (1910) and Evans (1966) studied the genus and described only 10 species from Brazil. Recently SANTos \& AzEvEDo (2000) revised 30 Brazilian species.

The Anisepyris fauna of Espírito Santo is composed by 8 known species from Cariacica (Reserva Biológica de Duas Bocas) and Colatina. In this study, four new species from the State Parks Cachoeira da Fumaça, Municipality of Alegre $\left(20^{\circ} 37^{\prime} 35^{\prime \prime} \mathrm{S}\right.$ and $\left.41^{\circ} 36^{\prime} 26^{\prime \prime} \mathrm{W}\right)$ and Forno Grande, Municipality of Castelo (20 $21^{\circ} 18^{\prime \prime} \mathrm{S}$ and $\left.41^{\circ} 05^{\prime} 45^{\prime \prime} \mathrm{W}\right)$ are described and illustrated. Two other species, Anisepyris lobatus Santos \& Azevedo, 2000 and Anisepyris rectus Santos \& Azevedo, 2000, are recorded, being $A$. rectus for the first time to Espírito Santo.

The material is deposited in the Coleção Entomológica da Universidade Federal do Espírito Santo (UFES) and Coleção Entomológica da Universidade de Vila Velha (UVCE).

Terminology and abbreviations used follow Evans (1964, 1966, 1982): WH - maximum width of head, including eyes; LH - length of head, apical margin of clypeus to median vertex crest; WF - width of front, measured at its minimum point; HE - maximum height of eye, measured in lateral view; WOT - width of ocellar triangle, including lateral ocelli; OOL - ocello-ocular line, minimum distance from eye to lateral ocellus. Tegument nomenclature as in EADY (1968) and HARRIS (1979).
The measures of hypopygium were made considering its greatest width and greatest length, including the lateral thorn. The length of epipygium was taken from the median distance between the anterior and posterior margins. Both the hypopygium and the epipygium were mounted between glass slides to allow accurate measuring. The illustrations of the mesosoma were made excluding the propodeum. The type specimens of $A$. lobatus and $A$. rectus were examined.

\section{Anisepyris attenuatus sp. nov.}

(Figs. 1-6)

Holotype, male. Body length $3.92 \mathrm{~mm}$; head $1.00 \mathrm{~mm}$; mesosoma $1.57 \mathrm{~mm}$; metasoma $1.35 \mathrm{~mm}$; fore wings length 2.97 $\mathrm{mm}$.

Color. Head, mesosoma and metasoma black; mandibles black, except distal third brown; antennae dark brown, scape black; palpi light brown; coxae black; trochanter, tarsi and fore tibiae brown; femora and hind tibiae dark brown; fore wings light brown; veins dark brown.

Head (Fig. 1). Shining. Mandibles with five teeth practically of same length, the first slightly broader than others. Clypeus angulate, seen in profile with high, arching median carina. First four antennal articles in a ratio of 12:3:2:10; article three $0.67 \mathrm{x}$ as long as wide. Ratio length/thickness of the antennal articles: three plus four 3.08x; four 2.50x; eleven 2.50x. Antennal scrobe with inconspicuous carina, not reaching mesal margin of the 
eye. Frons coriaceous, with inconspicuous punctures separated from one another about $4 \mathrm{x}$ their own diameter. WH $0.97 \mathrm{x} \mathrm{LH}$; WF 0.64x WH; WF 1.26x HE; WOT 0.90x OOL. Vertex slightly convex in frontal view. Occipital carina not visible in dorsal view.

Mesosoma (Fig. 2). Shining. Pronotum and mesoscutum coriaceous, with small inconspicuous punctures, separated from one another about $4 \mathrm{x}$ their own diameter. Pronotal disc $2.32 \mathrm{x}$ as wide as long; anterior margin with inconspicuous carina; lateral margin not carinate; posterior margin paralleled by series of foveae. Propodeal disc $1.13 \mathrm{x}$ as wide as long, with five distinct discal carinae; disc transversely striate between carinae. Mesopleuron (Fig. 3) coriaceous; lower mesopleural fovea fully open on the upper margin. Mid tibiae without dorsal spines. Front femora 2.87x as long as wide. Claws trifid.

Metasoma. 1.90x as long as wide; shining, basal tergites smooth; gaster covered with brown hairs, except on basal tergites. Hypopygium (Fig. 6) 2.14x as wide as long. Genitalia (Figs. 4, 5): paramere 2.40x as long as wide; apical margin oblique; dorsal margin straight; ventral margin arched; pubescence restricted to the apical and ventral margins; internal face of paramere with one seta about the median area. Cuspis with narrowed dorsal ramus in the apex; ventral ramus digitshaped; digitus as long as cuspis; aedeagus as long as digitus, with basal half dilated and oval and apical half narrow, rounded at apex. Baseparamere with a small median projection.

Material examined. Holotype, male. BRAZIL. Espirito Santo: Castelo, Forno Grande State Park, 13.X.2000, sweeping, about $1100 \mathrm{~m}$, H.S. Santos col. (UFES). Paratypes: 4 males, BRAZIL, 3 males, same data as holotype, except 1 male C.O. Azevedo col. and 1 male 14.X.2000; 1 male, BRAZIL, Espírito Santo, Alegre, Cachoeira da Fumaça State Park, 11.X.2000, sweeping, 500 m, H.S. Santos col. (UFES).

Variation. Body length 3.84-4.45 mm; fore wings length 2.70 $3.00 \mathrm{~mm}$. Frons and thoracic dorsum with very tenuous olivegreen reflections. Frons barely coriaceous. Clypeus seen in profile with median carina nearly straight. Pronotal disc 2.12 $2.46 \mathrm{x}$ as wide as long, its posterior margin with an inconspicuous series of parallel foveae. Propodeal disc 1.09$1.18 \mathrm{x}$ as wide as long. Front femura $2.55-2.82 \mathrm{x}$ as long as wide. Metasoma 2.16-2.49x as long as wide. Genitalia very similar in all the specimens.

Remarks. The Brazilian species of Anisepyris have been characterized by presence of a transversal carina on the anterior margin of the pronotal disc. However, in Anisepyris attenuatus sp. nov. the anterior carina of the pronotum is very weak and illdefined. This fact is not common in the species from Brazilian fauna, so that in recent study of SANTOS \& AzEvEDo (2000) none species were reported with this characteristic. However, Evans (1966) has been reported this fact to some species from Costa Rica, Cuba, Guatemala, Guyana and Honduras.

Distribution. Brazil (Espírito Santo).

Etymology. From Latin, attenuatus: weak, tenuous. Name referring to very weak and inconspicuous anterior carina of the pronotal disc.

\section{Anisepyris divisus sp. nov.}

(Figs. 7-12)

Holotype, male. Body length $4.75 \mathrm{~mm}$ : head $1.10 \mathrm{~mm}$, mesosoma $1.75 \mathrm{~mm}$, metasoma $1.90 \mathrm{~mm}$; fore wings length 3.13 $\mathrm{mm}$.

Color. Frons and thoracic dorsum black with olive-green reflections; propodeum and metasoma black; mandibles black, except teeth rufo-brown; antennae dark brown; scape black; palpi light brown; coxae and femora black; trochanter, tibiae and tarsi light brown, except hind tibiae dark brown; fore wings light brown; veins dark brown.

Head (Fig. 7). Shining. Mandibles with five teeth practically of same length, except the first tooth slightly larger. Clypeus angulate, seen in profile with a high, slightly arching median carina. First four antennal articles in a ratio of 17:4:3:9; article three $0.75 \mathrm{x}$ as long as wide. Ratio length/thickness of the antennal articles: three plus four 3.00x; four 2.25x; eleven 2.67x. Antennal scrobe carinate, however not reaching the mesal margin of the eye. Frons weakly coriaceous, with punctures small but well defined, separated from one another about 1-2x their own diameter. WH 1.02x LH; WF 0.62x WH; WF 1.17x HE; WOT $0.87 x$ OOL. Vertex slightly convex in frontal view. Occipital carina not visible in dorsal view.

Mesosoma (Fig. 8). Shining. Pronotum and mesoscutum slightly coriaceous, with punctures more widely spaced than on frons. Pronotal disc $2.44 \mathrm{x}$ as wide as long; distinctly carinate anteriorly and laterally; posterior margin paralleled by series of foveae. Propodeal disc 1.46x as wide as long, with five distinct discal carinae and two weaker carinae at each side close to median carina; disc transversely striate between carinae. Mesopleuron (Fig. 9) weakly coriaceous; lower mesopleural fovea partially open on the upper margin. Mid tibiae without dorsal spines. Front femora $2.41 \mathrm{x}$ as long as wide. Claws trifid.

Metasoma. 2.05x as long as wide; very shining, basal tergites smooth; gaster covered with brown hairs, except on basal tergites. Hypopygium (Fig. 12) 1.62x as wide as long. Genitalia (Figs. 10, 11): paramere biramous, dorsal ramus slightly enlarged apically, with 4-5 very long apical setae; ventral ramus longer than dorsal ramus, apical third broad, with several setae much smaller than those of the ventral ramus; cuspis with dorsal ramus tapering toward the apex; ventral ramus digit-shaped; volsella with about 4-5 very small setae at base of the digitus; aedeagus with a deep dorsal depression at the apical third in profile, ventral half with a small laminar prominence.

Material examined. Holotype, male. BRAZIL. Espírito Santo: Castelo, Forno Grande State Park, 13.X.2000, sweeping, about 1100 m, H.S. Santos col. (UFES).

Remarks. Species very similar to Anisepyris trinitatis Evans, 1966, from which it differs only by the genitalia. In Anisepyris divisus sp. nov. the base of paramere is wider, the dorsal and 


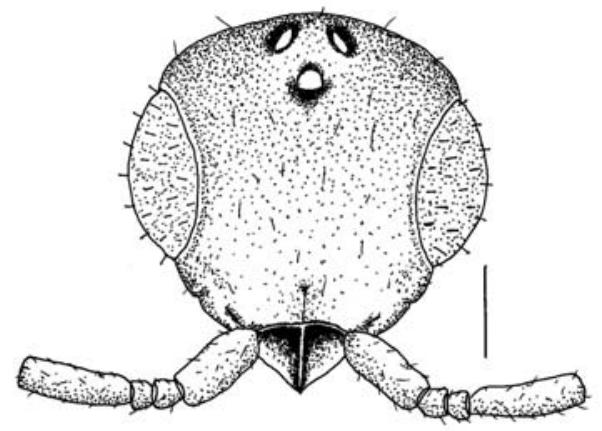

1

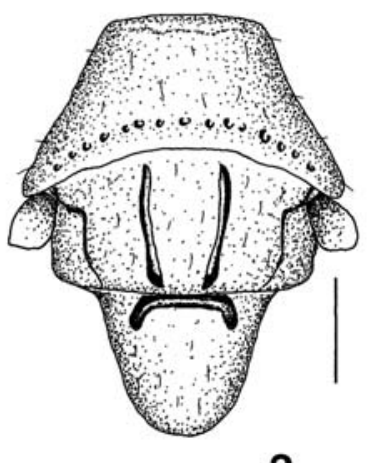

2

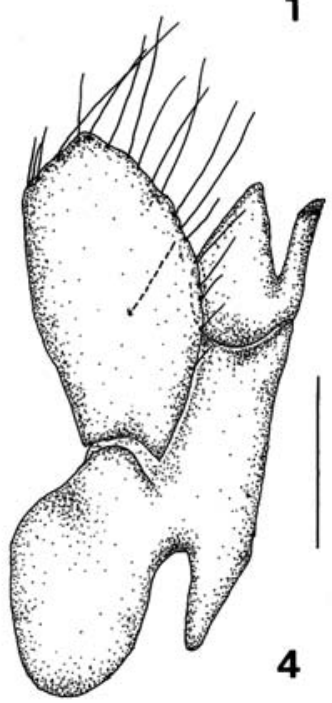

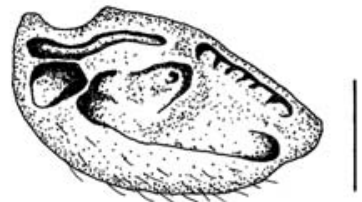

3

Figs. 1-6. Anisepyris attenuatus sp. nov., holotype, male. 1, head, frontal view; 2, mesosoma, dorsal view without propodeum; 3, mesopleuron, lateral view; 4, genitalia, ventral view; 5, genitalia, lateral view; 6, hypopygium, dorsal view; scales: figs. 1-3=0,25 mm; figs. 4-6=0,15 mm.

ventral ramus shorter and wider, and the setae of the dorsal ramus are less numerous and restricted to the apex.

Distribution. Brazil (Espírito Santo).

Etymology. From Latin, divisus: separate, divided. Name referring to the division of the paramere in two branches.

\section{Anisepyris inconspicuus sp. nov.}

(Figs. 13-18)

Holotype, male. Body length $5.34 \mathrm{~mm}$; head $1.25 \mathrm{~mm}$; mesosoma $1.97 \mathrm{~mm}$; metasoma $2.12 \mathrm{~mm}$; fore wings length 3.50 $\mathrm{mm}$.

Color. Frons and thoracic dorsum black with olive-green reflections; propodeum and metasoma black; mandibles black, except teeth rufo-brown; antennae black; palpi brown; fore coxae black; mid and hind coxae brown; legs dark brown, except fore tibiae and tarsi light brown; fore wings light brown; veins dark brown.
Head (Fig. 13). Shining. Mandibles with five teeth, first to third of same length, fourth and fifth smaller. Clypeus angulate, seen in profile with a high, arching median carina. First four antennal articles in a ratio of 14:4:2:15; article three $0.50 \mathrm{x}$ as long as wide. Ratio length/thickness of the antennal articles: three plus four 3.40x; four 3.00x; eleven 3.07x. Antennal scrobe with a feeble carina, not reaching the mesal margin of the eye. Frons coriaceous, with distinct punctures and separated from one another about 1-1.5x their own diameter. WH 0.94x LH; WF 0.61x WH; WF 1.27x HE; WOT 0.92x OOL. Vertex convex in frontal view. Occipital carina not visible in dorsal view.

Mesosoma (Fig. 14). Shining. Pronotum and mesoscutum coriaceous, with punctures separated from one another about $2-4 \mathrm{x}$ their own diameter. Pronotal disc $2.35 \mathrm{x}$ as wide as long; anterior carinae forming only very weak, ill-defined striae; lateral margin not carinate; posterior margin paralleled by series of foveae. Propodeal disc $1.07 \mathrm{x}$ as wide as long, with five distinct discal carinae; disc transversely striate between carinae. Mesopleuron (Fig. 15) very weakly coriaceous; lower mesopleural fovea slightly foveolate, broadly open on the upper 

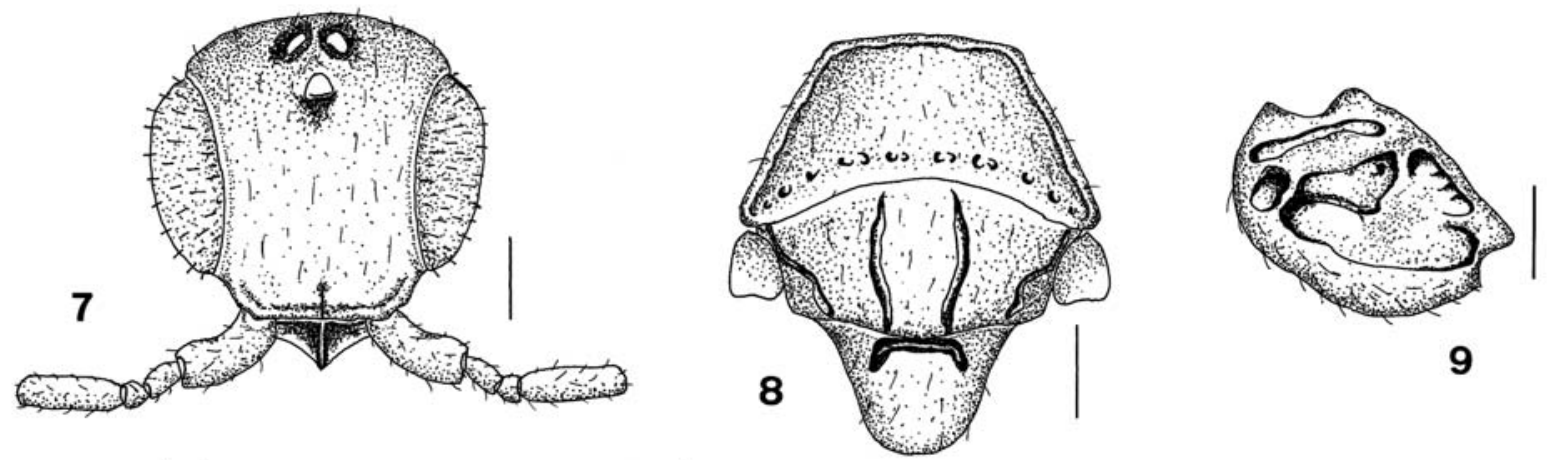

9
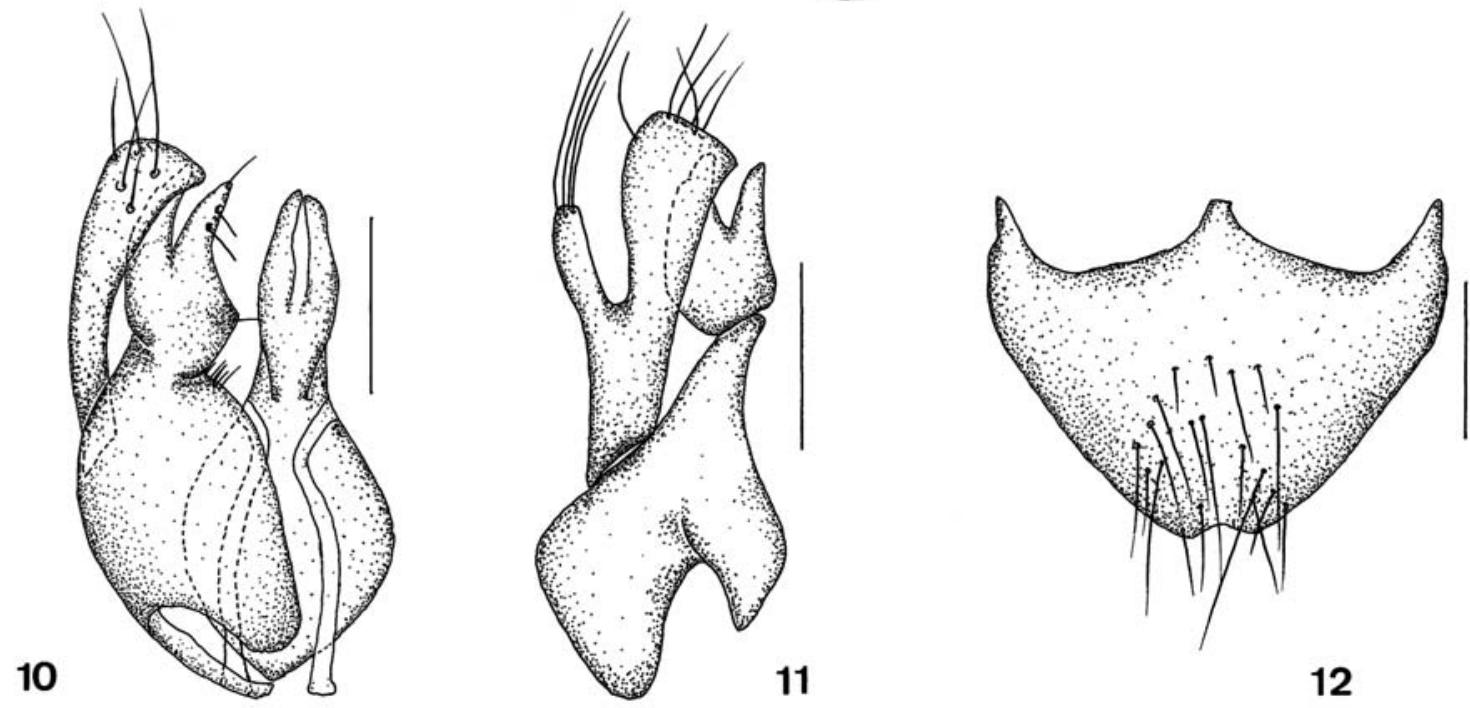

11

12

Figs. 7-12. Anisepyris divisus sp. nov., holotype, male. 7, head, frontal view; 8, mesosoma, dorsal view without propodeum; 9, mesopleuron, lateral view; 10, genitalia, ventral view; 11, genitalia, lateral view; 12, hypopygium, dorsal view; scales: figs. 7-9=0,26 mm; figs. 10-12=0,15 mm.

and lower margin. Mid tibiae without dorsal spines. Front femora $2.70 \mathrm{x}$ as long as wide. Claws trifid.

Metasoma. 2.50x as long as wide; very shining, basal tergites smooth; gaster covered with brown hairs, except on basal tergites. Hypopygium (Fig. 18) 1.72x as wide as long. Genitalia (Figs. 16, 17): paramere 2.00x as long as wide; apical margin obtuse; dorsal margin straight; ventral margin arched; pubescence restricted to the apical part, and part of the ventral margin. Cuspis with dorsal ramus tapering toward the apex; ventral ramus digit-shaped; digitus as long as cuspis; aedeagus as long as digitus, with basal half dilated and oval, and apical half narrow, rounded at apex. Baseparamere with inner margin concave.

Material examined. Holotype, male. BRAZIL. Espírito Santo: Castelo, Forno Grande State Park, 15.X.2000, sweeping, 2039 m, C.O. Azevedo col. (UFES).

Remarks. The species is similar to Anisepyris attenuatus sp. nov. from which it differs mainly by having the anterior carina of the pronotal disc pratically absent, the lower fovea of mesopleuron broadly open on the lower margin, the paramere broader and the inner margin of baseparamere longer and concave.

Distribution. Brazil (Espírito Santo).

Etymology. From Latin, inconspicuus: not readily visible, not prominent. Name referring to the practically absent anterior carina of the pronotal disc.

\section{Anisepyris rotundus sp. nov.}

(Figs. 19-25)

Holotype, female. Body length: $6.40 \mathrm{~mm}$; head: $1.30 \mathrm{~mm}$; mesosoma: $2.30 \mathrm{~mm}$; metasoma: $2.80 \mathrm{~mm}$; fore wings length: $4.00 \mathrm{~mm}$.

Color. Frons and thoracic dorsum black, with very weak coppery reflections under certain lights; propodeum black; metasoma black, with apical segments rufo-brown; mandibles 

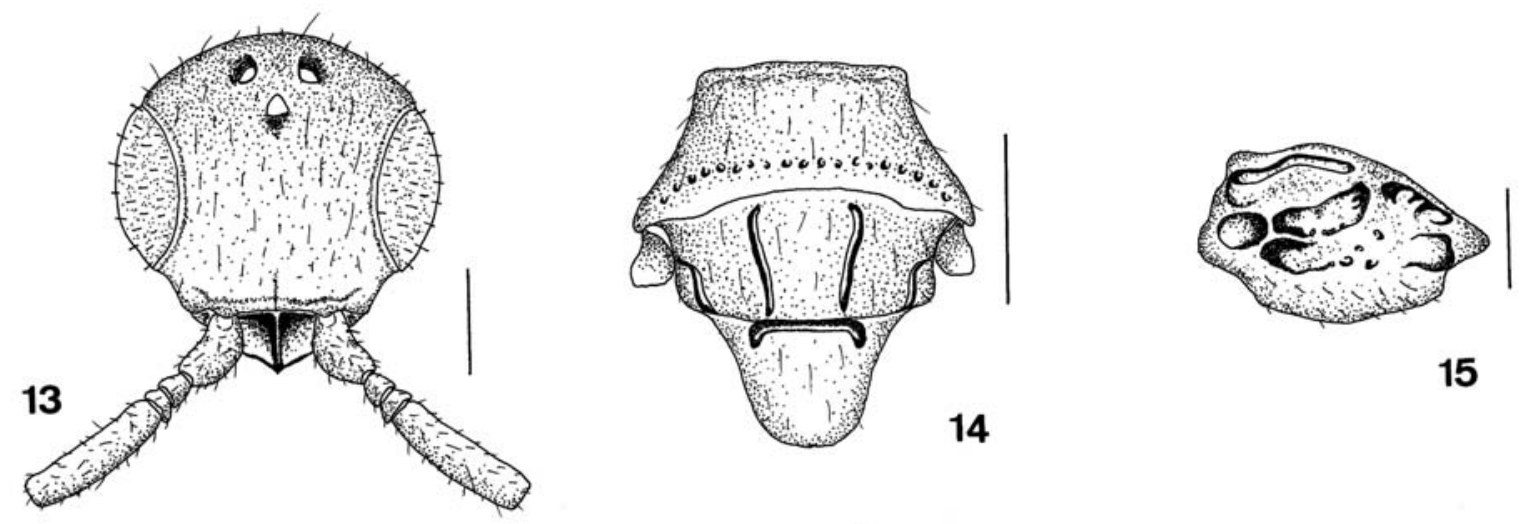

15
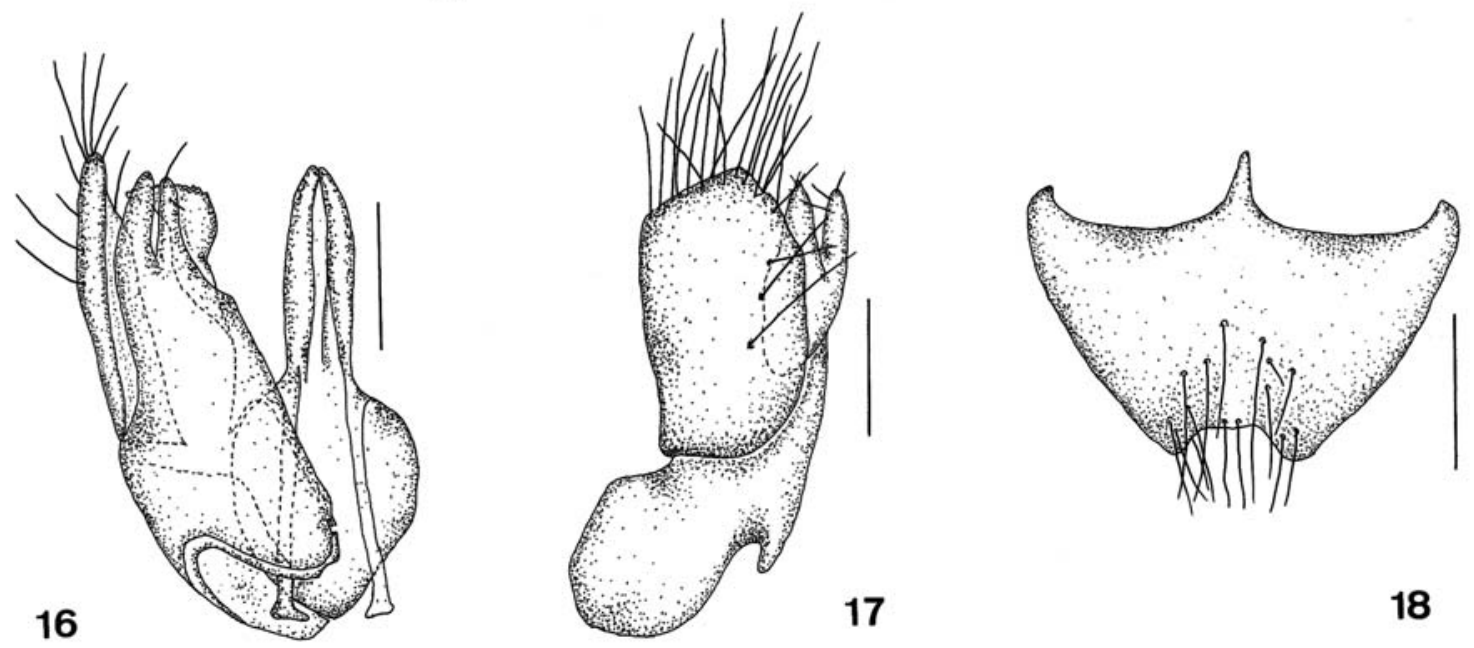

17

18

Figs. 13-18. Anisepyris inconspicuus sp. nov., holotype, male. 13, head, frontal view; 14, mesosoma, dorsal view without propodeum; 15, mesopleuron, lateral view; 16, genitalia, ventral view; 17, genitalia, lateral view; 18, hypopygium, dorsal view; scales: figs. 13-15=0,40 mm; figs. 16$18=0,15 \mathrm{~mm}$.

black, except apical third dark rufo-brown; antennae rufobrown; palpi brown; legs rufo-brown, except coxae and hind femora black; fore wings light brown, slightly darkened along radial vein; veins brown.

Head (Fig. 19). Shining. Mandibles from second to fifth teeth forming a broad cutting edge. Clypeus rounded, the median line with a rounded elevation surmounted by a delicate carina. First four antennal articles in a ratio of 23:6:5:7; article three $1.00 \mathrm{x}$ as long as wide. Ratio length/thickness of the antennal articles: three plus four 2.20x; four 1.19x; eleven 1.22x. Scape $2.61 \mathrm{x}$ as long as wide. Antennal scrobe not carinate. Frons coriaceous, with small punctures well defined and separated from one another about $1-2 \mathrm{x}$ their own diameter. WH 1.06x LH; WF 0.62x WH; WF 1.03x HE; WOT 0.89x OOL. Vertex straight with rounded corners in frontal view. Occipital carina not visible in dorsal view.

Mesosoma (Fig. 20). Shining. Pronotum and mesoscutum slightly coriaceous, with punctures more widely spaced than on frons. Pronotal disc $2.12 \mathrm{x}$ as wide as long; distinctly carinate anteriorly and laterally; posterior margin paralleled by series of foveae most conspicuous on the median third. Propodeal disc $1.48 \mathrm{x}$ as wide as long, with five distinct discal carinae and two weaker carinae at each side close to median carina; lateral discal carinae reaching the paramedian carinae; disc transversely striate between carinae; posterior corner of the disc with a round and deep fovea. Mesopleuron (Fig. 21) weakly coriaceous; lower mesopleural fovea divided in two by a distinct and vertical ridge, its posterior half open on the upper margin. Mid tibiae without dorsal spines. Front femora $1.89 x$ as long as wide. Claws trifid.

Metasoma. 2.05x as long as wide; very shining, basal tergites smooth; gaster covered with brown hairs, except on basal tergites. Hypopygium (Fig. 24) 0.70x as wide as long; anterior margin U-shaped, the corners ending in a sharp lateral 

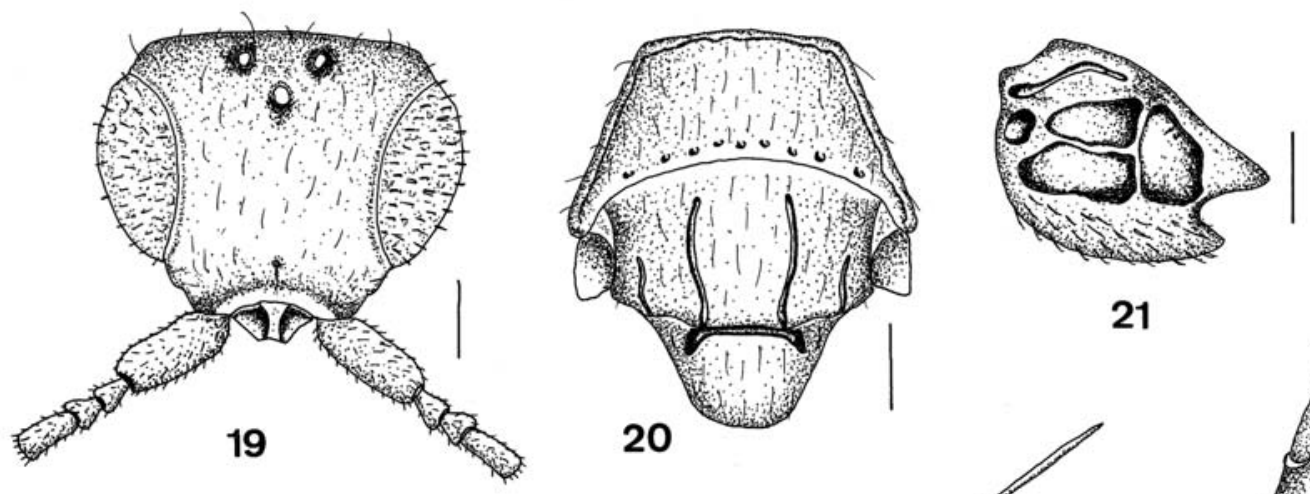

20
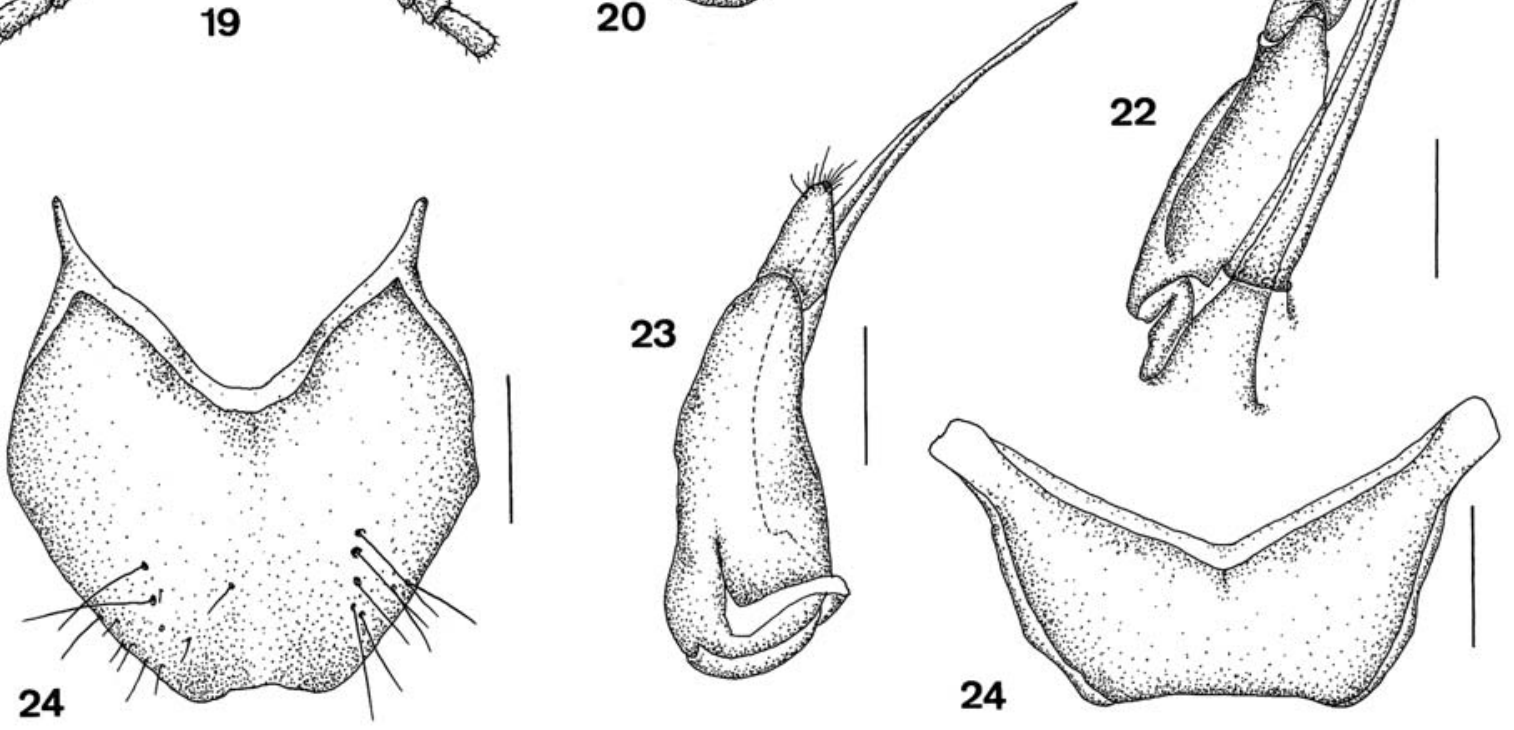

Figs. 19-25. Anisepyris rotundus sp. nov., holotype, female. 19, head, frontal view; 20, mesosoma, dorsal view without propodeum; 21, mesopleuron, lateral view; 22, ovipositor, ventral view; 23, ovipositor, lateral view; 24, hypopygium, dorsal view; 25, epipygium, dorsal view; scales: figs. 19$21=0,35 \mathrm{~mm}$; figs. $22-25=0,30 \mathrm{~mm}$.

thorn; setae on the postero-lateral ventral margin numerous and long; median posterior area with several very short setae. Epipygium (Fig. 25) 3.28x as wide as long; anterior margin Vshaped and posterior margin straight. Ovipositor (Figs. 22, 23) sheath strongly thin toward to the apex, with a small ventral prominence in half of length. Ovipositor 1.16x as long as hypopygium.

Material examined. Holotype, female. BRAZIL. Espirito Santo: Castelo, Forno Grande State Park, 14.X.2000, sweeping, about $1100 \mathrm{~m}$, C.O. Azevedo col. (UFES).

Remarks. In $A$. rotundus sp. nov., the mesopleuron is very similar to that of Anisepyris smithanus (Westwood, 1874). However, it differs from $A$. smithanus mainly by having the propodeal disc black, head much narrower(WH 1.06x LH), vertex straight, antennal scrobe not carinate and posterior margin of pronotal disc with a series of small parallel foveae. It differs from Anisepyris eganellus (Westwood, 1874), mainly by having the head very narrow and the frons rounded, not forming a deep arched depression just above the clypeus. I had some difficulties to insert $A$. rotundus sp. nov. in the venustus group because the ratio $\mathrm{WH} / \mathrm{LH}$ is smaller than that established for the species of this group. However, by other external morphologic characters, mainly the mesopleuron, it was possible to consider $A$. rotundus sp. nov. as belonging to the venustus group.

Distribution. Brazil (Espírito Santo).

Etymology. From Latin, rotundus: rounded. Name referring to the rounded anterior margin of the frons.

Anisepyris lobatus Santos \& Azevedo, 2000

Anisepyris lobatus Santos \& Azevedo, 2000: 154.

Anisepyris lobatus was known only from Cariacica, Espírito 
Santo, Brazil. Body length of the specimens 3.54-3.96 mm (head 0.87-0.97 mm; mesosoma 1.32-1.42 mm; metasoma 1.32-1.57 mm), fore wings length $2.41-2.63 \mathrm{~mm}$.

Material examined. 1 male. BRAZIL. Espirito Santo: Castelo, Forno Grande State Park, 14.X.2000, sweeping, about 1100 m, C.O. Azevedo col. (UFES).

Variation. The specimen is very similar to the holotype; body length $3.44 \mathrm{~mm}$; fore wings length $2.47 \mathrm{~mm}$; metasoma and legs lighter than in the type; clypeus seen in profile with median carina less arched; antennal article three $0.50 \mathrm{x}$ as long as wide; ratio length/thickness of the antennal articles: three plus four $3.17 \mathrm{x}$; four $2.00 \mathrm{x}$; eleven $2.31 \mathrm{x}$; frons with inconspicuous punctures; WH 0.97x LH; WF 0.65x WH; WF 1.29x HE; WOT 0.89x OOL; pronotal disc 2.59x as wide as long; propodeal disc $1.21 \mathrm{x}$ as wide as long; front femora $2.57 \mathrm{x}$ as long as wide.

Distribution. Brazil (Espírito Santo).

Anisepyris rectus Santos \& Azevedo, 2000

Anisepyris rectus Santos \& Azevedo, 2000: 151.

Anisepyris rectus has been recorded only from Distrito Federal and São Paulo with eleven specimens collected by Möricke and Malaise trap. The ocurrence of $A$. rectus in Espírito Santo is recorded for the first time. Body length 4.54-5.52 mm (head: 0.92-1.12 mm; mesosoma: 1.55-1.95 mm; metasomsa: 1.97$2.47 \mathrm{~mm}$ ); fore wings length $2.77-3.33 \mathrm{~mm}$.

Material examined. 2 males: BRAZIL. Espírito Santo: Alegre, Cachoeira da Fumaça State Park, 11-12.X.2000, sweeping, about 500 m, C.O. Azevedo col. (UFES)

Variation. Body length 4.28-4.44 mm; fore wings length 3.03$3.10 \mathrm{~mm}$; mandibles, antennae, eyes, legs, tegulae, wings, veins and metasoma darker than in the type; antennal article three
$0.72-0.93 \mathrm{x}$ as long as wide; ratio length/thickness of the antennal articles: three plus four 2.97-3.05x; four 2.25-2.31x; eleven 2.552.67x; WH 1.03-1.06x LH; WF 0.64-0.65x WH; WF 1.23-1.27x HE; WOT 0.95x OOL; frons and thoracic dorsum less coriaceous than in the type; ocellar triangle more compact than in the type; pronotal disc 2.41-2.49x as wide as long; notaulus narrow; propodeal disc 1.56-1.62x as wide as long; lower mesopleural fovea broadly open above; front femora $2.40-2.45 \mathrm{x}$ as long as wide; paramere $3.00 \mathrm{x}$ as long as wide, with the setae restricted to the apical third; prominence at the base of the digitus more distinct and with two small setae at the apex.

Distribution. Brazil (Distrito Federal, Espírito Santo, São Paulo).

Acknowledgements. I thank Alexandre P. Aguiar and the anonymous reviewers for the revision of the manuscript, and Celso O. Azevedo for the loan of the types of Anisepyris lobatus and Anisepyris rectus.

\section{REFERENCES}

EADY, R. D. 1968. Some illustrations of microsculpture in the Hymenoptera. Proceedings of the Royal Entomological Society of London 43:66-72.

Evans, H. E. 1964. A synopsis of the American Bethylidae (Hymenoptera, Aculeata). Bulletin of the Museum of Comparative Zoology 132:1-222.

Evans, H. E. 1966. A revision of the genus Anisepyris Kieffer (Hymenoptera, Bethylidae). Studia Entomologica 9:1-120.

Evans, H. E. 1982. The Anxius group of the genus Rhabdepyris Kieffer (Hymenoptera, Bethylidae: Epyrinae). Journal of the Australian Entomological Society 21:55-61.

KiefFer, J. J. 1910. Description de nouveaux béthylides [Hymén.]. Annales de la Société Entomologique de France 79:31-56.

Harris, R. A. 1979. A glossary of surface sculpturing. Occasional Papers in Entomology, 28:1-31.

Santos, H. S. \& C. O. AzEvedo 2000. Sistemática das espécies de Anisepyris Kieffer, 1905 (Hymenoptera, Bethylidae) do Brazil. Revista Brasileira de Entomologia 44(3/4):129-165.

Westwood, J. O. 1874. Thesaurus Entomologicus Oxoniensis. Oxford, Clarendon Press, 205 p., 40 pls. 